Bulgarian Academy of Sciences. Space Research and Technology Institute. Aerospace Research in Bulgaria. 30, 2018, Sofia

DOI: https://doi.org/10.3897/arb.v30.e06

\title{
EVALUATION OF RAPIDEYE VEGETATION INDICES FOR PREDICTION OF BIOPHYSICAL/BIOCHEMICAL VARIABLES OF WINTER WHEAT
}

\author{
Ilina Kamenova ${ }^{1}$, Petar Dimitrov ${ }^{1}$, Rusina Yordanova ${ }^{2}$ \\ ${ }^{1}$ Space Research and Technology Institute - Bulgarian Academy of Sciences \\ e-mail: petarkirilov@mail.bg, ilina.kamenova@space.bas.bg \\ ${ }^{2}$ Sortovi Semena - Vardim EAD \\ e-mail: r_yordanova@abv.bg
}

\begin{abstract}
The aim of the study is to evaluate the possibility for using RapidEye data for prediction of Leaf Area Index (LAI), fraction of Absorbed Photosynthetically Active Radiation (fAPAR), fraction of vegetation Cover (fCover), leaf Chlorophyll Concentration (CC) and Canopy Chlorophyll Content $(C C C)$ of winter wheat. The relation of a number of vegetation indices (VIs) with these crop variables is accessed based on a regression analysis. Indices, which make use of the red edge band, such as Chlorophyll Index red edge (CIre) and red edge Normalized Difference Vegetation Index (reNDVI), were found most useful, resulting in linear models with $R^{2}$ of 0.67, 0.71, 0.72, and 0.76 for fCover, LAI, $C C C$, and fAPAR respectively. CC was not related with any of the VIs.
\end{abstract}

\section{Introduction}

RapidEye is a remote sensing mission consisting of a constellation of five small satellites launched in 2008. One of the main applications of the RapidEye satellite data is to provide timely information about the crop condition in support of precision agriculture [1]. To better fulfil this aim, the Multi-spectral Imager on board RapidEye has a band in the red edge spectral region in addition to the visible and the near infrared (NIR) bands.

RapidEye data has been previously used for estimation of crop variables. For example, Vuolo et al. [2] compared physically based (Radiative Transfer Modelling) and empirical (Vegetation Indices) approaches for retrieval of LAI and CCC using RapidEye imagery. In their study, one regression model was applied for a range of crops (fruit trees, maize, and other crops). Using generally calibrated model, however, may not provide equally good estimates for all crops. In this study, we are only interested in winter wheat and the aim is to investigate empirical relations between VIs and biophysical variables that are specific for this crop. 


\section{Data and methods}

\section{Field data}

For this study, measurements of biophysical and biochemical variables of winter wheat are available from fields located in the north-western part of Sofia municipality, close to the residential district of Trebich. Measurements of Leaf Area Index (LAI), fraction of Absorbed Photosynthetically Active Radiation (fAPAR), fraction of vegetation Cover (fCover) and leaf Chlorophyll Concentration (CC) were conducted seven times during the growing seasons of 2014-2015 and 2015-2016 (Table 1). During the 2014-2015 growing season, 5 plots in each of 2 fields were measured each time. During the 2015-2016 growing season 5 fields were sampled in a total of 11 plots (one of the plots was not sampled in 18/05/2016, see Table 1). In both seasons, the fields were sown with winter wheat Enola variety. In most of these seven field campaigns the full set of variables (i.e. LAI, fAPAR, fCover and CC) were measured; however fCover were not measured on 02/04/2015 and CC was not measured on $15 / 05 / 2015$. Measurements were made within a plot with size $5 \mathrm{~m} \times 5 \mathrm{~m}$. AccuPAR LP80 (Decagon Devices $($ ) ) was used for measuring LAI, fAPAR and fCover in 4 "subplots" in each plot. Portable chlorophyll meter CCM-300 was used for measuring CC ( $\left.\mathrm{mg} \mathrm{m}^{-2}\right)$ in 5-6 "subplots" in each plot. The averages of the "subplots" measurements were used in further analysis to represent the biophysical/biochemical variables at the plot level. Using the CC and LAI measurements, the canopy chlorophyll content (CCC) was calculated, where CCC $\left(\mathrm{g} \mathrm{m}^{-2}\right)=\mathrm{LAI}\left(\mathrm{m}^{2} \mathrm{~m}^{-2}\right) \times \mathrm{CC}\left(\mathrm{mg} \mathrm{m}^{-2}\right) \times 0.001$. Fig. 1 provide some graphical description of data.

Table 1. Dates of the field campaigns and the corresponding RapidEye images used in this study

\begin{tabular}{cclc}
\hline Growing season & Field campaign & Development stage & RapidEye image \\
\hline $2014-2015$ & $02 / 04 / 2015$ & Tillering & $31 / 03 / 2015$ \\
$2014-2015$ & $15 / 04 / 2015$ & Stem elongation & $20 / 04 / 2015$ \\
$2014-2015$ & $04 / 05 / 2015$ & Stem elongation & $12 / 05 / 2015$ \\
$2014-2015$ & $15 / 05 / 2015$ & Booting and heading & $18 / 05 / 2015$ \\
$2014-2015$ & $20 / 05 / 2015$ & Heading and start of anthesis & $21 / 05 / 2015$ \\
$2015-2016$ & $13 / 04 / 2016$ & Stem elongation & $13 / 04 / 2016$ \\
$2015-2016$ & $18 / 05 / 2016$ & Heading & $23 / 05 / 2016$ \\
\hline
\end{tabular}



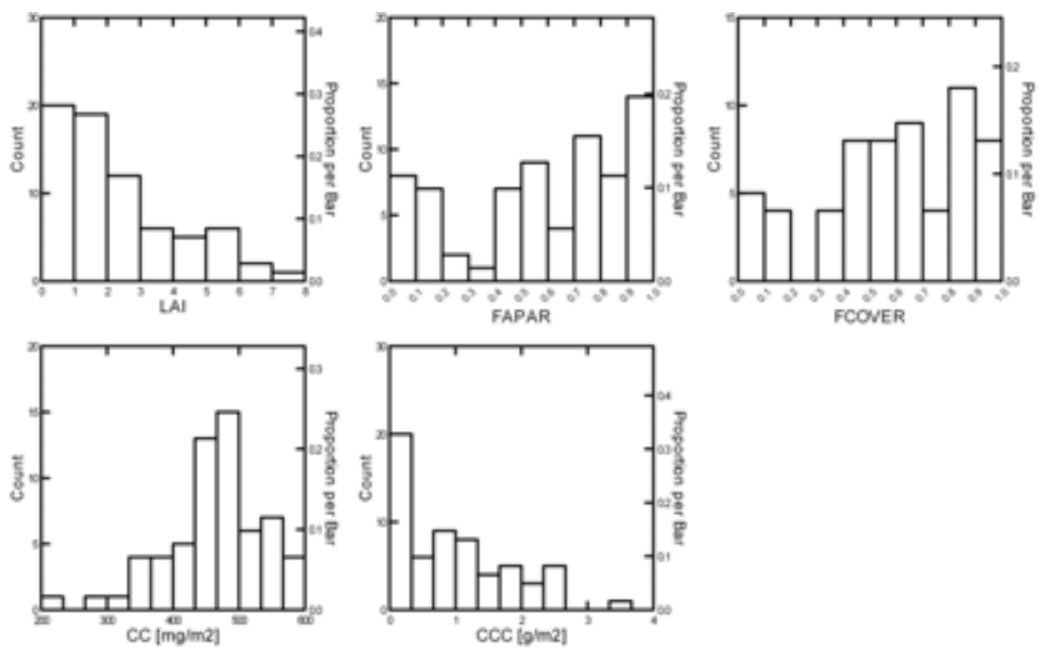

Fig. 1. Histograms of ground measured LAI $(n=71$; mean $=2.25)$, fAPAR $(n=71$; mean $=0.58)$, fCover $(n=61$, mean $=0.60)$, Chlorophyll Concentration $(C C)(n=61$; mean $=463)$ and Canopy Chlorophyll Content $(C C C)(n=61 ;$ mean $=0.96)$

\section{RapidEye data}

Seven RapidEye images were available for this study, which dates roughly corresponded to the dates of the field campaigns (Table 1). The separation between date of field campaign and image acquisition was between 0 and 5 days with only one occasion when the gap was 13 days (Table 1). The images are provided as Level3A (Ortho product) and showed highly accurate geo-registration as assessed by visual inspection of road vector map superimposed on the images. Each scene consists of five spectral bands: B1-Blue $(440-510 \mathrm{~nm})$; B2-Green $(520-590 \mathrm{~nm})$; B3-Red (630-685 nm); B4-Red edge $(690-730 \mathrm{~nm})$ and B5-Near infrared $(760-850 \mathrm{~nm})$. The spatial resolution is $5 \mathrm{~m}$ for all bands. The image data were transformed from DN to spectral radiance $\left(L_{\lambda}\right)$ using the provided scale factor [3]. Then, the top of the atmosphere (TOA) reflectance $\rho_{\lambda}$ was calculated using the equation:

$$
\rho_{\lambda}=\frac{\pi \times L_{\lambda} \times d^{2}}{E S N_{\lambda} \times \cos \theta_{S}},
$$

where $L_{\lambda}$ is Spectral radiance $\left[\mathrm{W} /\left(\mathrm{m}^{2} \mathrm{sr} \mu \mathrm{m}\right)\right], d$ is Earth-Sun distance [astronomical units], $E S U N_{\lambda}$ is Mean exoatmospheric solar irradiance [W/( $\left.\left.\mathrm{m}^{2} \mu \mathrm{m}\right)\right], \theta s$ is Solar zenith angle [degrees] [4]. The values of $E S U N_{\lambda}$ for each RapidEye band and of $\theta s$ for each acquisition date are available in the image product metadata. 


\section{Methods}

A database was constructed prior to the analysis, consisting of the biophysical/biochemical measurements, the reflectance values in each RapidEye band and a range of vegetation indices (VIs). The RapidEye reflectance values for a specified plot are extracted using bilinear interpolation, which is a method providing an estimated value that represents a weighted average of the 4 input pixels surrounding the plot centre. This approach was taken, instead of using only the pixel with the closest centroid, in order to account for possible errors in the GPS-measured plot coordinates. As the RapidEye spatial resolution (i.e. $5 \mathrm{~m}$ ) is comparable with the GPS accuracy this precaution is justified. The list of vegetation indices is presented in Table 2 .

Table 2. Spectral vegetation indices calculated in this study using RapidEye data.

The RapidEye band numbers are used in the formulas

\begin{tabular}{|c|c|c|c|}
\hline Vegetation Index & Abbreviation & Formula & Reference \\
\hline Chlorophyll Index red edge & CIre & $(\mathrm{B} 5 / \mathrm{B} 4)-1$ & {$[5,6]$} \\
\hline Chlorophyll Index green & $\mathrm{CIg}$ & $(\mathrm{B} 5 / \mathrm{B} 2)-1$ & {$[5,6]$} \\
\hline $\begin{array}{l}\text { Normalized Difference Vegetation } \\
\text { Index }\end{array}$ & NDVI & $(\mathrm{B} 5-\mathrm{B} 3) /(\mathrm{B} 5+\mathrm{B} 3)$ & {$[7]$} \\
\hline Simple Ratio & SR & $\mathrm{B} 5$ / B3 & {$[8]$} \\
\hline NIR/RE & NIR/RE & $\mathrm{B} 5$ / B4 & \\
\hline RE/RED & RE/RED & B4 / B3 & \\
\hline $\begin{array}{l}\text { Visible Atmospherically Resistant } \\
\text { Index }\end{array}$ & VARI & $(\mathrm{B} 2-\mathrm{B} 3) /(\mathrm{B} 2+\mathrm{B} 3-\mathrm{B} 1)$ & {$[9]$} \\
\hline $\begin{array}{l}\text { red edge Normalized Difference } \\
\text { Vegetation Index }\end{array}$ & reNDVI & $(\mathrm{B} 5-\mathrm{B} 4) /(\mathrm{B} 5+\mathrm{B} 4)$ & {$[10]$} \\
\hline $\begin{array}{l}\text { Wide Dynamic Range Vegetation } \\
\text { Index }\end{array}$ & WDRVI & $(0.3 \times \mathrm{B} 5-\mathrm{B} 3) /(0.3 \times \mathrm{B} 5+\mathrm{B} 3)$ & [11] \\
\hline Vegetation Index green & VIg & $(\mathrm{B} 2-\mathrm{B} 3) /(\mathrm{B} 2+\mathrm{B} 3)$ & [9] \\
\hline $\begin{array}{l}\text { Optimized Soil-Adjusted } \\
\text { Vegetation Index }\end{array}$ & OSAVI & $\begin{array}{l}(1+0.16) \times(\mathrm{B} 5-\mathrm{B} 3) /(\mathrm{B} 5+\mathrm{B} 3 \\
+0.16)\end{array}$ & {$[12]$} \\
\hline $\begin{array}{l}\text { green Normalized Difference } \\
\text { Vegetation Index }\end{array}$ & gNDVI & $(\mathrm{B} 5-\mathrm{B} 2) /(\mathrm{B} 5+\mathrm{B} 2)$ & [13] \\
\hline \multirow{2}{*}{$\begin{array}{l}\text { Modified Triangular Vegetation } \\
\text { Index } 2\end{array}$} & \multirow[t]{2}{*}{ MTVI2 } & $1.5 *\left[1.2 *\left(\mathrm{~B}_{5}-\mathrm{B}_{2}\right)-2.5 *\left(\mathrm{~B}_{3}-\mathrm{B}_{2}\right)\right]$ & \multirow[t]{2}{*}{ [14] } \\
\hline & & $\sqrt{(2 * B 5+1)^{2}-(6 * B 5-5 \sqrt{B 3})-0.5}$ & \\
\hline $\begin{array}{l}\text { Green Infrared Percentage } \\
\text { Vegetation Index }\end{array}$ & GIPVI & $\mathrm{B} 5$ / (B5 + B2) & \\
\hline $\begin{array}{l}\text { green Normalized Difference } \\
\text { Vegetation Index } 1\end{array}$ & gNDVI1 & $(\mathrm{B} 4-\mathrm{B} 2) /(\mathrm{B} 4+\mathrm{B} 2)$ & \\
\hline Perpendicular Vegetation Index ${ }^{\dagger}$ & PVA & $(\mathrm{B} 5-\mathrm{a} \times \mathrm{B} 3-\mathrm{b}) /\left(\mathrm{SQRT}\left(1+\mathrm{a}^{2}\right)\right)$ & {$[15]$} \\
\hline $\begin{array}{l}\text { Transformed Soil Adjusted } \\
\text { Vegetation index }+\$\end{array}$ & TSAVI & $\begin{array}{l}(\mathrm{a} \times(\mathrm{B} 5-\mathrm{a} \times \mathrm{B} 3-\mathrm{b})) /(\mathrm{a} \times \mathrm{B} 5+ \\
\left.\mathrm{B} 3-\mathrm{ab}+\mathrm{X} \times\left(1+\mathrm{a}^{2}\right)\right)\end{array}$ & {$[16]$} \\
\hline Soil Adjusted Vegetation index $2 \uparrow$ & SAVI2 & $\mathrm{B} 5 /(\mathrm{B} 3+(\mathrm{b} / \mathrm{a}))$ & {$[17]$} \\
\hline
\end{tabular}

$\uparrow \mathrm{a}$ and $\mathrm{b}$ are the slope and the intercept of the soil line (see Fig. 2); $₫ \mathrm{X}=0.08$ 
The vegetation indices were selected based on a literature review. Special emphasis was placed on the VIs that used bands from the red edge spectral region. Also, three soil adjusted VIs were calculated, Perpendicular Vegetation Index (PVI, [15]), Transformed Soil Adjusted Vegetation index (TSAVI, [16]), and Soil Adjusted Vegetation index 2 (SAVI2, [17]). The soil adjusted VIs used the parameters of the soil line in their formulas. The soil line was derived empirically using manually selected bare soil and stubble pixels (Fig. 2). Stubble pixels were used because crop residue may constitute significant part of the background reflectance in the winter wheat fields.

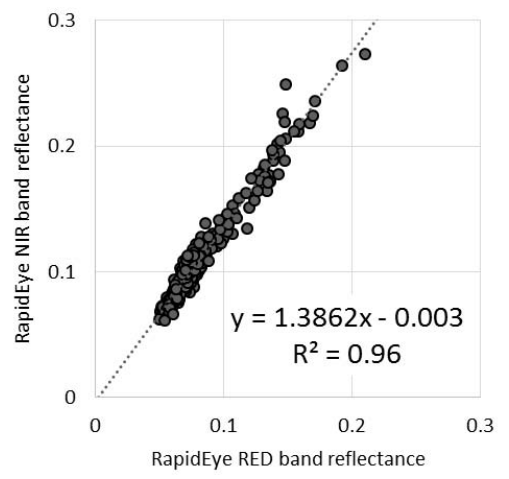

Fig. 2. Near infrared (NIR) band reflectance regressed on the red band reflectance for soil/stubble pixels from RapidEye (image data 31 March 2015, 20 April 2015 and 13 April 2016)

We used two approaches to compare the potential of different VIs for prediction of biophysical/biochemical variables. First, the association of each biophysical/biochemical variables with each VI was visually assessed using scatterplots. The second, quantitative, approach was based on the regression analysis. All VIs were systematically evaluated by fitting linear and exponential models with each biophysical/biochemical variable being dependant variable. These two models have the form $\mathrm{y}=\mathrm{a}+\mathrm{bx}$ and $\mathrm{y}=\mathrm{a} \times \mathrm{e}^{\mathrm{bx}}$ respectively, where $a$ and $b$ are the regression parameters to be estimated. Literature suggested that, in most cases, the relation between biophysical/biochemical variable of crop and spectral vegetation index can be described by one of these two models. We used regression analysis, instead of some measure of correlation, because the interest is on the prediction capabilities. This approach also permitted us to account explicitly for the type of the relation, i.e. linear or nonlinear. The Root Mean Square Error (RMSE) was calculated for each model using the leave-one-out method:

$$
R M S E=\sqrt{\frac{\sum_{i}\left(y_{i}-\hat{y}_{i}\right)^{2}}{n}},
$$


where $y_{i}$ is the measured value for the $i$-th observation and $\hat{y}_{i}$ is the predicted value for that observation derived from a model calibrated with all observations except $i$. The RMSE was used as a criterion for the performance of the VIs. Note that not every model produced in this procedure makes sense. For example, if the relation between a VI and LAI is curve-linear then fitting a straight line to this data would be erroneous. For every given combination of biophysical/biochemical variable and VI the lower RMSE may indicate which model (linear or exponential) might be more appropriate but one should not rely on this. In any case, the scatterplot must be checked.

For this analysis, we did not pay attention for the regression assumptions because the aim was to make some automated and consistent comparison of a number of VIs and found those that may represent interest for further analysis.

\section{Results}

The scatterplots obtained from RapidEye VIs against the five winter wheat biophysical/biochemical variables are displayed in Fig. 3. Fig. 4 shows the RMSE of the fitted linear and exponential models for each combination.

The scatterplots suggest that LAI is most strongly correlated with Chlorophyll Index red edge (CIre) (this index is, in practice, equivalent to the NIR/RE ratio (see Table 2)). The form of the relation may be roughly described as linear but some outliers (low LAI values corresponding to high CIre) contradict this general trend. The regression analyses confirm that the best linear predictor of LAI is CIre (RMSE = 1.05). Exponential model is more appropriate to describe the relation of LAI to some of the other VIs such as the red edge Normalized Difference Vegetation Index (reNDVI). The RMSE of the exponential model with reNDVI is 1.06. Thus, similar results are obtained using linear and exponential models.

The fAPAR and fCover behave very similarly with respect to their relation with the VIs. In general, the scatter of data points is high, which indicates relatively poor relationship for most VIs (Fig. 3). The linear models with lowest error are those with reNDVI (RMSE $=0.16$ for both fAPAR and fCover), but other indices such as NDVI, TSAVI and OSAVI perform almost equally well. The exponential model form was not appropriate for any of the VIs.

There was no correlation between CC and the tested VIs. This is probably because other factors, such as background reflectance and canopy structure mask the differences in CC at leaf level. CCC showed better association with the VIs but this is not surprising because the variation of CCC is affected mostly by the variation of LAI. As with LAI, the best model is the linear model with CIre which yielded RMSE of $0.47 \mathrm{~g} \mathrm{~m}^{-2}$. 
On Fig. 6 are shown the best performing linear model for each biophysical/biochemical variable. The models explain between $67 \%$ (fCover) and $76 \%$ (fAPAR) of the variability of the dependent variable. In general, the level of uncertainty is too high for these models to provide reliable estimates at pixel level. Even though the predictions are not precise, they are unbiased as indicated by the mean residuals, which are close to zero for all models (data not shown). This may be important if the estimates are to be aggregated at field or regional level.
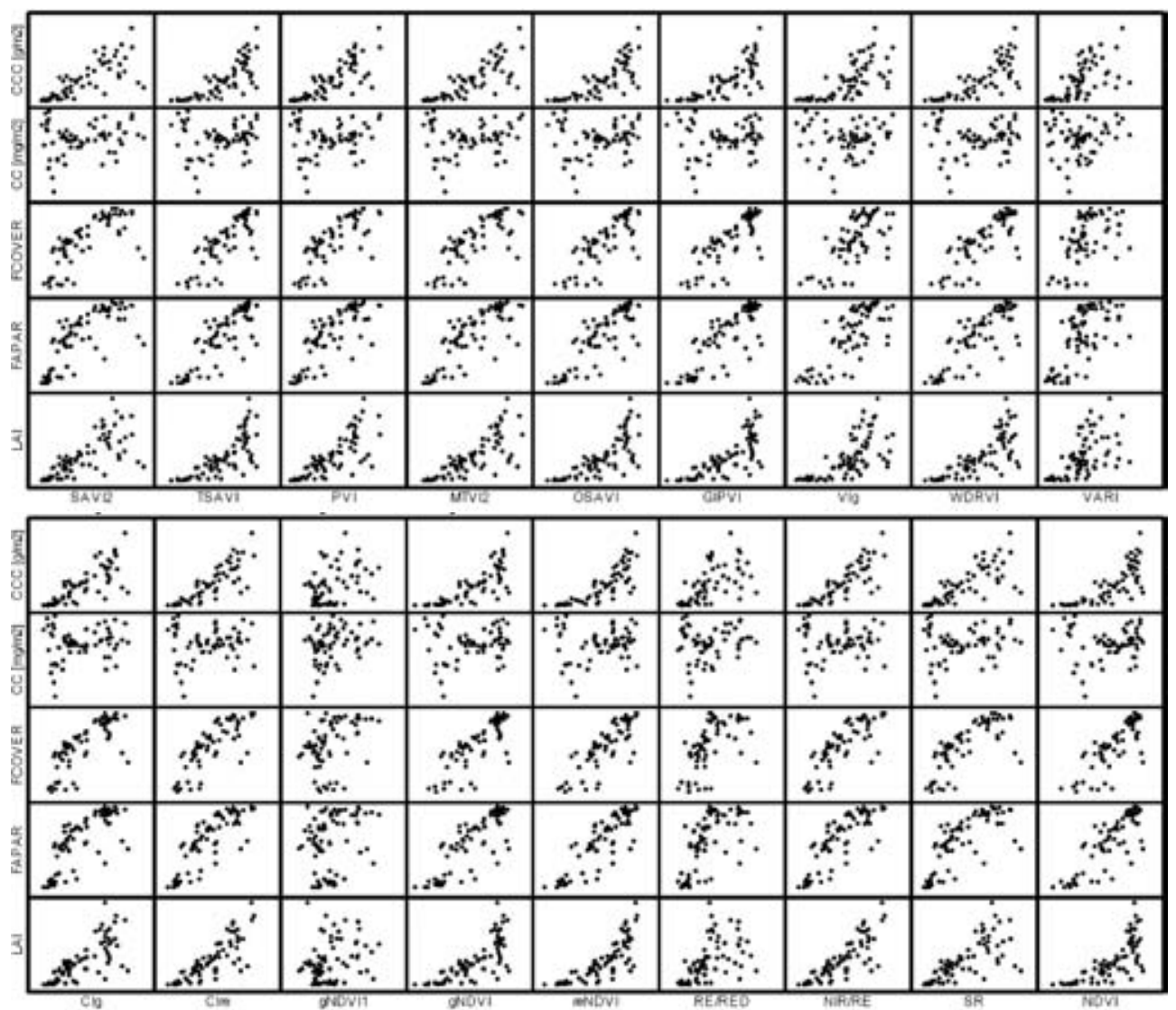

Fig. 3. Scatterplots of the studied biophysical/biochemical variables and the RapidEye vegetation indices

Characteristic for both LAI and CCC is the increasing dispersion with the increase of CIre. Predictions become more uncertain approaching the peak of the growing season in May when winter wheat is in heading and anthesis phenological stages. The team led by Dahms [18] has also found that LAI and FPAR are difficult 
to predict at the phenological phase of fruit development, which, according to the authors, is most likely due to canopy closure in combination with accompanied saturation effects in the RapidEye observations.

None of the tested soil adjusted vegetation indices improved significantly the prediction capabilities of the models probably because the variation in background reflectance was not an important factor for the observed prediction uncertainty. A paper by Ali et al. [19] showed that a similar index to those used in our study, the Soil Adjusted Vegetation Index, do not necessarily outperform NDVI in the estimation of LAI with RapidEye. As shown, most uncertainty is related with the closed canopies, while the soil adjusted VIs are designed to improve the relation with the vegetation parameters in open canopies where soil contribution is significant [20].

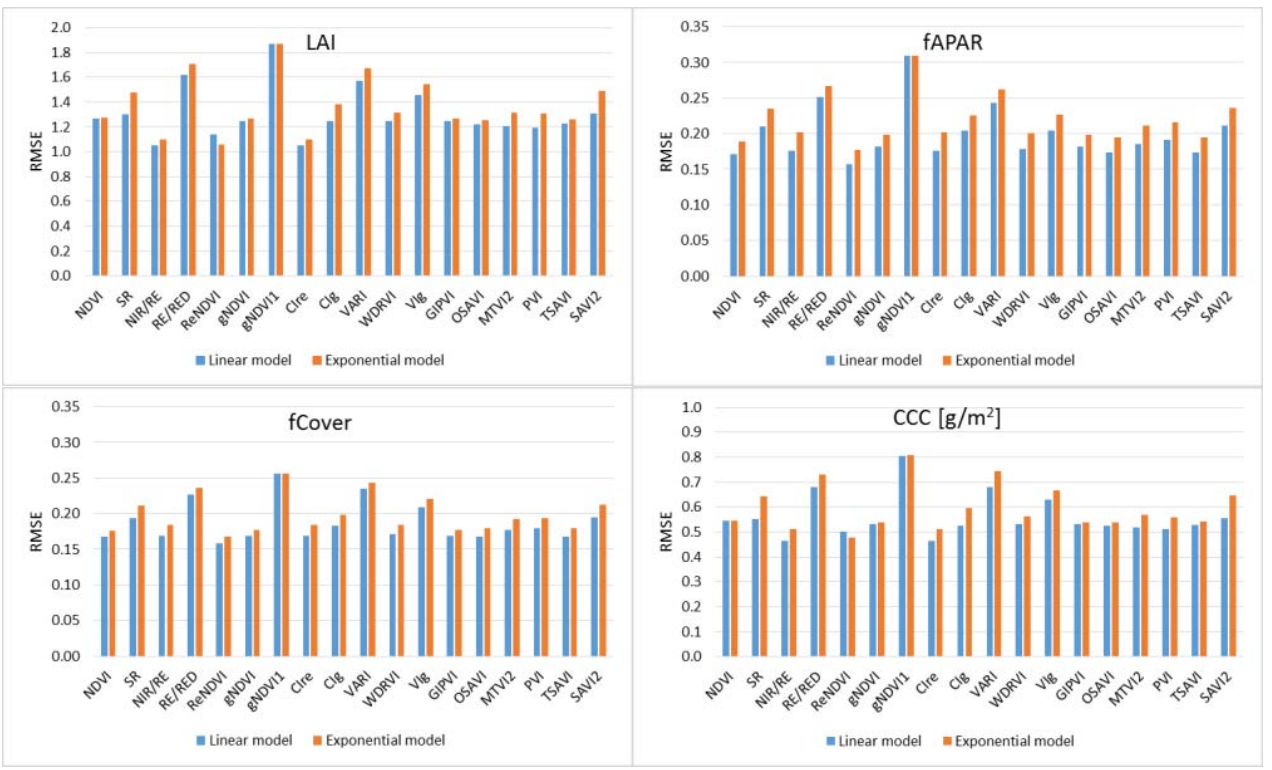

Fig. 4. Comparison of the accuracy (RMSE = root mean square error) of regression models employing different vegetation indices. Both linear and exponential models for prediction of LAI, fAPAR, fCover, and CCC are shown.

The regression models were assessed using the RMSE value. The best models were used for calculation of prediction maps for the targeted biophysical/biochemical parameters. CIre was the index with the lowest RMSE value among other indices for predicting LAI in winter wheat. The RMSE showed relatively low error of $1.05 \mathrm{~m}^{2} \mathrm{~m}^{-2}$.

The LAI maps were calculated using vegetation index map with the spectral values from each RapidEye image, and the coefficients derived from the regression 
analysis. On Fig. 5 are represented the LAI maps derived for each of the available RapidEye images from vegetation season 2015.

The resulting map consisted of one layer, whereby each pixel in the map had a value for the predicted LAI. The predicted values based on the linear regression coefficients of the CIre relation resulted in some pixels with negative values. The negative LAI result is of course not possible in the reality, but the values are result of a simple linear mathematical function. However, the fraction of the pixels having negative LAI values, can be attributed to pixels with exposed soil cover. This is the reason to find larger proportion of pixels with negative values during the first two dates (31/03/2015 and 20/04/2015).

In the maps is shown the infield variation of LAI, which could be of interest for the farmers for the management practices. On the other hand, the 6 maps also show the seasonal dynamic of LAI during the vegetation season.
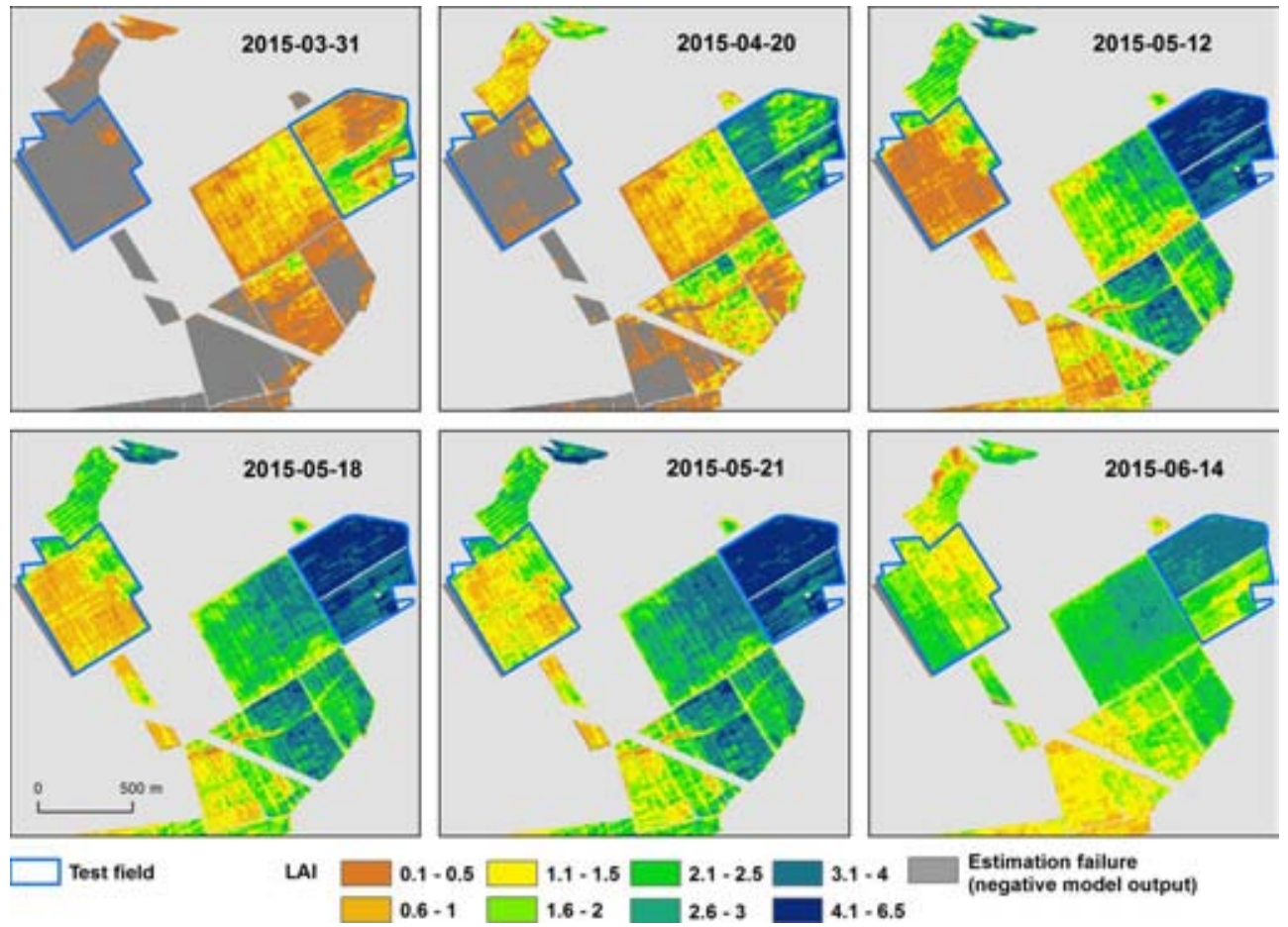

Estimation failure (negative model output)

Fig. 5. Predicted LAI $\left(\mathrm{m}^{2} \mathrm{~m}^{-2}\right)$ maps for winter wheat

\section{Conclusions}

In this study, we compared a range of VIs calculated from RapidEye data with respect to their potential for prediction of LAI, fAPAR, fCover, CC, and CCC in winter wheat fields (Fig. 6). Of these biophysical/biochemical variables, only CC 
was not significantly correlated with any of the tested VIs. For prediction of LAI and CCC, the most useful indices appear to be CIre and reNDVI, for which linear and exponential regression models are appropriate respectively. We found that reNDVI is the best predictor of fAPAR and fCover, but that several other indices perform almost equally well. Both reNDVI and CIre employ the red edge band, which confirm the importance of the red edge spectral region for crop condition characterisation. Note however, that it is possible for several VIs to show similar results and more data are needed to find if given VI should be preferred to the others.
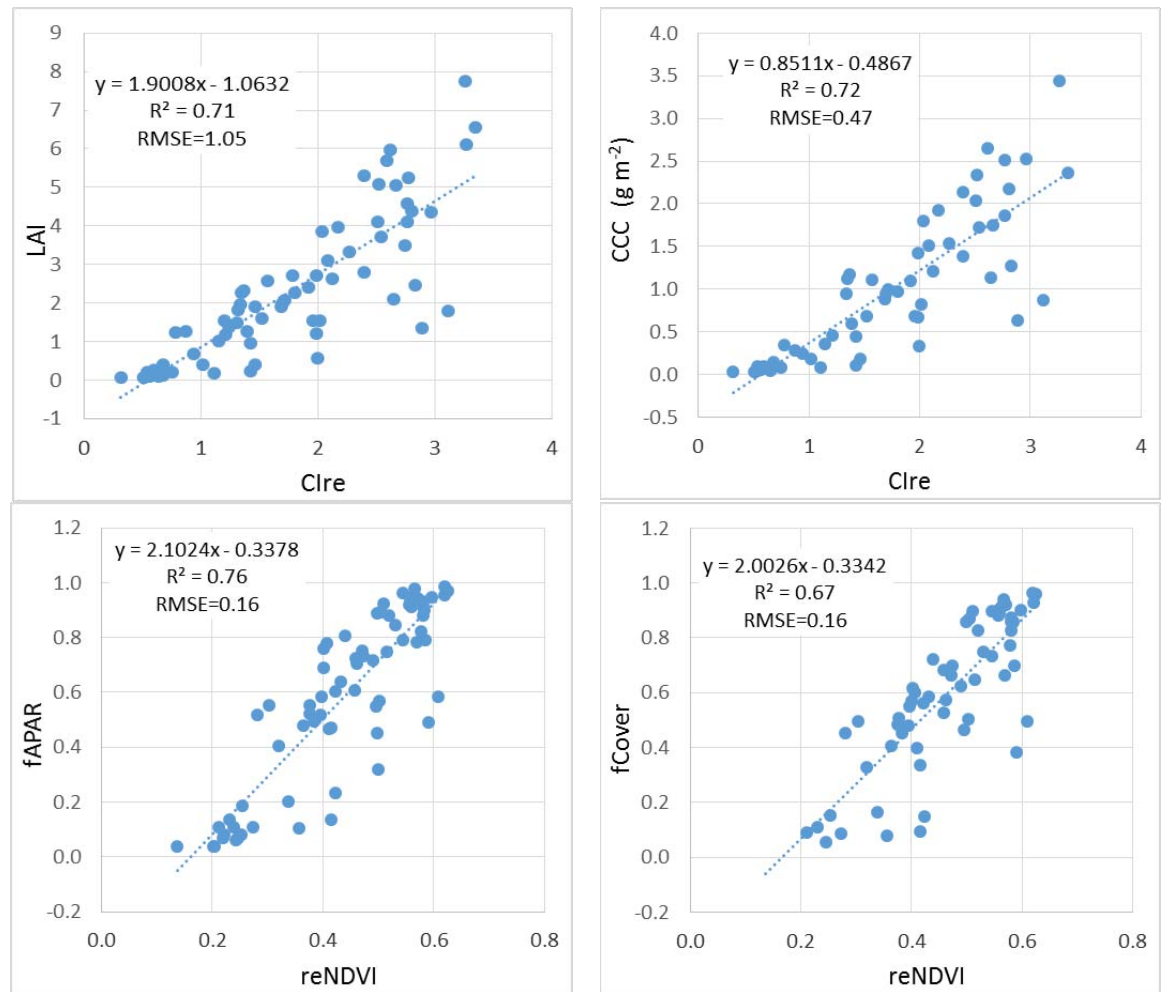

Fig. 6. Linear regression models for LAI, fAPAR, fCover and CCC with selected VIs from RapidEye

The accuracy of the regression models presented in this study is relatively low. This may be due to atmospheric effects on the satellite data, presence of weeds on the field plots or other factors. In conclusion, VIs from RapidEye employing the red edge band are promising for winter wheat variables characterization, but further experimental work is needed to better understand the sources of uncertainty and eventually increase prediction accuracy of the regression models. 


\section{Acknowledgments}

This study was funded by the Bulgarian Academy of Sciences through the Young Scientists and PhD Students Support Programme (Grant № ДФНП-17-177). The RapidEye imagery was provided by ESA (Category-1 Project ID 29490). The authors are grateful to Ms V. Todorova from the co-operative in Trebich for providing access to the fields and to G. Jelev and Y. Naydenov who helped with the fieldwork.

\section{References}

1. Tyc, G., J. Tulip, D. Schulten, M. Krischke, and M. Oxfort. The RapidEye mission design. Acta Astronautica, 2005, 56, 213-19.

2. Vuolo, F., C. Atzberger, K. Richter, G. D'Urso, and J. Dash. Retrieval of biophysical vegetation products from RapidEye imagery. In: Wagner W., Székely, B. (eds.): ISPRS TC VII Symposium - 100 Years ISPRS, Vienna, Austria, July 5-7, 2010, IAPRS, Vol. XXXVIII, Part 7A, 281-86.

3. BlackBridge. Satellite Imagery Product Specifications, Version 6.1, April 2015, 48 p.

4. Chander, G., B. L. Markham, and D. L. Helder. Summary of current radiometric calibration coefficients for Landsat MSS, TM, ETM+, and EO-1 ALI sensors. Remote Sensing of Environment, 2009, 113, 893-903.

5. Gitelson, A., Y. Gritz, and M.N. Merzlyak. Relationships between leaf chlorophyll content and spectral reflectance and algorithms for non-destructive chlorophyll assessment in higher plant leaves. Journal of Plant Physiology, 2003, 160, 271-82.

6. Gitelson, A., G.P. Keydan, and M.N. Merzlyak. Three-band model for noninvasive estimation of chlorophyll, carotenoids, and anthocyanin contents in higher plant leaves. Geophys. Res. Lett., 2006, 33, L11402, DOI:10.1029/2006GL026457.

7. Rouse, J.W., R.H. Haas, J.A. Schell, and D.W. Deering. Monitoring vegetation systems in the Great Plains with ERTS. In: Third ERTS Symposium, 1973, NASA SP-351, vol. 1, NASA, Washington, DC, 309-317.

8. Jordan, C.F. Derivation of leaf-area index from quality of light on the forest floor. Ecology, 1969, 50, 663-66.

9. Gitelson, A., Y.J. Kaufman, R. Stark, and D. Rundquist. Novel algorithms for remote estimation of vegetation fraction. Remote Sensing of Environment, 2002, 80, 76-87.

10. Gitelson, A., and M.N. Merzlyak. Spectral reflectance changes associated with autumn senescence of Aesculus hippocastanum L. and Acer platanoides L. Leaves.Spectral features and relation to chlorophyll estimation. J. Plant Physiol., 1994, 143, 286-92.

11. Gitelson, A. Wide Dynamic Range Vegetation Index for Remote Quantification of Biophysical Characteristics of Vegetation. J. Plant Physiol., 2004, 161, 165-73.

12. Rondeaux, G., M. Steven, and F. Baret. Optimization of soil-adjusted vegetation indices. Remote Sensing of Environment, 1996, 55, 2, 95-107.

13. Gitelson, A., Y.J. Kaufman, and M.N. Merzlyak. Use of a green channel in remote sensing of global vegetation from EOS-MODIS. Rem. Sens. Envir., 1996, 58, 289-98. 
14. Haboudane, D., J.R. Miller, E. Pattey, P.J. Zarco-Tejada, and I.B. Strachan. Hyperspectral vegetation indices and novel algorithms for predicting green LAI of crop canopies: modelling and validation in the context of precision agriculture. Remote Sensing of Environment, 2004, 90, 337-52.

15. Richardson, A.J., and J.H. Everitt. Using Spectral Vegetation Indices to Estimate Rangeland Productivity. Geocarto International, 1992, 7, 1, 63-69.

16. Baret, F., G. Guyot. Potentials and limits of vegetation indices for LAI and APAR assessment. Remote Sensing of Environment, 1991, 35, 161-73.

17. Major, D. J., F. Baret, and G. Guyot. A ratio vegetation index adjusted for soil brightness. International Journal of Remote Sensing, 1990, 11, 727-40.

18. Dahms, T., S. Seissiger, E. Borg, H. Vajen, B. Fichtelmann, C. Conrad. Important Variables of a RapidEye Time Series for Modelling Biophysical Parameters of Winter Wheat. PFG, 2016, 5 - 6, 285-99. DOI: 10.1127/pfg/2016/0303.

19. Ali, M., C. Montzka, A. Stadler, G. Menz, F. Thonfeld, and H. Vereechen. Estimation and Validation of RapidEye-Based Time-Series of Leaf Area Index for Winter Wheat in the Rur Catchment (Germany). Remote Sensing, 2015, 7, 2808-31, DOI:10.3390/rs70302808.

20. Bannari, A., D. Morin, F. Bonn, and A.R. Huete. A review of vegetation indices. Remote sensing reviews, 1995, 13, 95-120.

\title{
ИЗСЛЕДВАНЕ НА ВЪЗМОЖНОСТИТЕ ЗА ОПРЕДЕЛЯНЕ НА БИОФИЗИЧНИ/БИОХИМИЧНИ ПОКАЗАТЕЛИ НА ЗИМНА ПШЕНИЦА ЧРЕЗ ВЕГЕТАЦИОННИ ИНДЕКСИ OT RAPIDEYE
}

\author{
И. Каменова, П. Димитров, Р. Йорданова
}

\section{Резюме}

Целта на изследването е да оцени възможностите за приложение на данни от спътниковата система RapidEye за определяне на индекса на листната повърхност (LAI), дела на погълнатата фотосинтетично активна радиация (fAPAR), проективното покритие (fCover), концентрацията на хлорофил в листата (CC) и хлорофилното съдържание в растенията на единица площ от земната повърхност (CCC) на посеви от зимна пшеница. Връзката на тези показатели с различни вегетационни индекси е изследвана чрез регресионен анализ. Индекси използващи спектралния канал „red-edge“ на RapidEye, като например Chlorophyll Index red edge (CIre) и red-edge Normalized Difference Vegetation Index (reNDVI) са най-полезни, позволявайки съставянето на линейни регресионни модели с детерминационни коефициенти 0.67, 0.71, 0.72 и 0.76 съответно за fCover, LAI, CCC и fAPAR. Концентрацията на хлорофил в листата не се корелира с никой от използваните вегетационни индекси. 